\title{
PENGARUH LABA AKUNTANSI, ARUS KAS OPERASI, ARUS KAS INVESTASI, ARUS KAS PENDANAAN, DAN UKURAN PERUSAHAAN TERHADAP RETURN SAHAM
}

\author{
Meta Nursita \\ Program Studi Akuntansi, Fakultas Ekonomi, Universitas Pamulang, Jl. Surya Kencana No. 1, Tangerang \\ Selatan, Kode Pos. 15412, Indonesia. \\ E-mail: dosen02628@unpam.ac.id
}

\begin{abstract}
This study aimed to examine the impact of accounting profit, operating cash flows, investment cash flows, financing cash flows and company size to stock returns on manufacturing firms sector for consumption by the corporate listed and registered under the Indonesia Stock Exchange within 2014 - 2016. This study employed Purposive Sampling method with a total of 39 companies taken as the sample in the present study. Data analysis process followed the following steps; descriptive statistical test, multicollinearity test, model fit test, regression model feasibility test, and hypothesis test. Statistical method used is panel data regression analysis. The result showed that accounting profit had partially significant impact on stock return; operating cash flows no had significant impact on stocks return; investment cash flows, and financing cash flows had no significant impact on stock return and company size had significant impact on stocks return. in addition, simultaneously, the results showed that the four aspects examined had statistically significant impact on stock return.
\end{abstract}

Keywords: accounting profit; operating cash flows; investment cash flows; financing cash flows; company size; stock return

\section{PENDAHULUAN}

Ketersediaan dana dan akses sumber dana yang besar memiliki pengaruh yang kuat terhadap kelangsungan hidup dalam perkembangan di dunia usaha. Dalam era persaingan usaha yang semakin kompetitif sekarang ini, perusahaan dituntut untuk dapat mengelola dan mempergunakan dana dengan sebaik mungkin salah satunya dengan mengelola dana ekternal perusahaan dalam pasar modal dimana pasar modal menjadi sarana pendanaan bagi perusahaan untuk menanamkan modal yang dimilikinya yang mengharuskan perusahaan bersaing secara sehat dalam rangka menarik investor agar menanamkan modal di perusahaannya dengan cara berinvestasi.

Pasar modal memiliki peran penting bagi perekonomian suatu negara karena pasar modal menjalankan dua fungsi, yaitu sebagai sarana bagi pendanaan usaha atau sebagai sarana bagi perusahaan untuk mendapatkan dana dari masyarakat pemodal (investor). Dana yang diperoleh dari pasar modal dapat digunakan untuk pengembangan usaha, ekspansi, penambahan modal kerja dan lain sebagainya, dan dalam fungsi yang kedua pasar modal menjadi sarana bagi masyarakat untuk berinvestasi pada instrumen keuangan seperti saham, obligasi, reksa dana, dan lain sebagainya. Dalam membuat keputusan investasi, investor sangat membutuhkan informasi yang akurat hal ini disebabkan karena investor mempunyai harapan dapat memperoleh keuntungan (return) berupa capital gain maupun dividend. Informasi yang paling mendasar bagi investor sebelum mengambil keputusan informasi adalah kinerja kerja perusahaan yang tercermin dari laporan keuangannya.

Laporan keuangan merupakan salah satu sumber informasi keuangan perusahaan yang di dalamnya mengandung informasi mengenai posisi keuangan, kinerja keuangan, dan arus 
kas entitas yang bermanfaat bagi sebagian besar kalangan pengguna laporan dalam pembuatan keputusan investasi. Laporan keuangan yang lengkap menurut Ikatan Akuntan Indonesia berdasarkan Pernyataan Standar Akuntansi Keuangan (PSAK) No. 1 tentang Penyajian Laporan Keuangan terdiri dari komponen-komponen berikut ini: (a) laporan posisi keuangan pada periode akhir; (b) laporan laba rugi komprehensif selama periode; (c) laporan perubahan ekuitas selama periode; (d) laporan arus kas selama periode; (e) catatan atas laporan keuangan, berisi ringkasan kebijakan akuntansi yang signifikan dan informasi penjelasan lain; (f) informasi komparatif mengenai periode terdekat sebelumnya sebagaimana ditentukan dalam paragraf 38 dan 38A; dan (g) laporan posisi keuangan pada awal periode terdekat sebelumnya ketika entitas menerapkan suatu kebijakan akuntansi. Laporan keuangan juga menunjukkan hasil pertanggungjawaban manajemen atas penggunaan sumber daya yang dipercayakan kepada manajemen perusahaan. Informasi yang terdapat dalam laporan keuangan meliputi aset, liabilitas, ekuitas, pendapatan dan beban termasuk laba atau rugi.

Laba merupakan salah satu elemen laporan keuangan yang memiliki kandungan informasi lebih tinggi. Laba sering dijadikan sumber utama untuk mengukur kinerja perusahaan. Laba merupakan kenaikan manfaat ekonomi selama satu periode akuntansi dalam bentuk pemasukan, perubahan aktiva atau penurunan kewajiban yang menyebabkan kenaikan ekuitas yang tidak berasal dari kontribusi penambahan modal. Laba akuntansi didefinisikan sebagai kenaikan manfaat ekonomi selama periode akuntansi dalam bentuk penambahan aktiva atau penurunan kewajiban yang mengakibatkan kenaikan ekuitas yang tidak berasal dari kontribusi penanaman modal selain untuk menilai kinerja laba akuntansi bisa juga digunakan untuk memprediksi kemampuan laba serta menaksir risiko dalam investasi dan kredit (Yocelyn dan Chistiawan, 2012). Dalam praktiknya, investor terkadang tidak meperoleh informasi laporan keuangan yang akurat untuk dijadikan acuan pengambilan keputusan karena adanya strategi window dressing atau manipulasi laporan keuangan yang dilakukan oleh perusahaan. Semestinya, laporan keuangan diharapkan dapat memberikan tolak ukur secara jelas terhadap prestasi keuangan perusahaan. Salah satu faktor yang dapat digunakan sebagai tolak ukur adalah laba atau income.

Selain laba, informasi penting lainnya yang diperoleh dari laporan keuangan adalah informasi arus kas. Laporan arus kas diklasifikasikan menjadi tiga menurut PSAK No. 2 yaitu aktivitas operasi, aktivitas investasi, dan aktivitas pendanaan. Pada laporan arus kas atas aktivitas operasi merupakan aktivitas penghasil utama pendapatan perusahaan (principal revenue activities) dan aktivitas lain yang bukan merupakan aktivitas investasi dan pendanaan. Aktivitas operasi berasal dari transaksi dan peristiwa lain yang mempengaruhi penetapan laba atau rugi bersih, dan merupakan indikator yang menentukan apakah dari operasi perusahaan dapat menghasilkan kas yang cukup untuk melunasi pinjaman, memelihara kemampuan operasi perusahaan, membayar dividen dan melakukan investasi baru tanpa mengandalkan sumber pendanaan dari luar. Anwar (2014) mengungkapkan bahwa arus kas dari aktivitas operasi tidak berpengaruh secara signifikan terhadap return saham. Hal ini sejalan dengan Latief dan Purwanto (2015) yang menyatakan bahwa arus kas operasi berpengaruh positif dan signifikan terhadap return saham, akan tetapi tidak sejalan dengan Daniati dan Suhairi (2006) yang menemukan bahwa informasi komponen laporan arus kas berpengaruh signifikan terhadap expected return saham.

Informasi penting lainnya dalam laporan arus kas selain arus kas aktivitas operasi, yaitu arus kas yang berasal dari arus kas aktivitas investasi dan arus kas aktivitas pendanaan. Dalam arus kas aktivitas investasi, arus kas investasi ini menyangkut perolehan atau pelepasan aktiva jangka panjang (aktiva tidak lancar) serta investasi lain yang tidak termasuk dalam setara kas, mencakup aktivitas meminjamkan uang dan mengumpulkan piutang serta memperoleh dan menjual investasi dan aktiva jangka panjang produktif. Arus kas aktivitas investasi mencerminkan pengeluaran kas sehubungan dengan sumber daya yang bertujuan 
untuk menghasilkan pendapatan dan arus kas masa mendatang di dalam perusahaan sedangkan pada arus kas pendanaan ini mengakibatkan perubahan dalam jumlah serta komposisi ekuitas dan pinjaman perusahaan. Arus kas pendanaan berguna untuk memprediksi klaim terhadap arus kas masa depan oleh para pemasok modal perusahaan. Latief dan Purwanto (2015) membuktikan bahwa arus arus kas investasi dan arus kas pendanaan berpengaruh positif dan signifikan terhadap return saham, sedangkan laba akuntansi berpengaruh positif dan tidak signifikan terhadap return saham sedangkan dividend yield berpengaruh negatif dan tidak signifikan terhadap return saham. Hal ini sejalan dengan Purwanti et al. (2015) yang menyatakan bahwa arus kas investasi tidak berpengaruh terhadap return saham, sedangkan arus kas pendanaan berpengaruh signifikan terhadap return saham.

Disisi lain, selain laba akuntansi dan arus kas operasi, arus kas investasi, dan arus kas pendanaan, ukuran perusahaan juga dapat mempengaruhi ketertarikan investor untuk melakukan investasi. Ukuran perusahaan juga dapat menunjukkan pengalaman dan kemampuan tumbuhnya suatu perusahaan yang dapat mengindikasi tingkat risiko dalam mengatur investasi para investor. Jika perusahaan mempunyai total aset yang besar tandanya perusahaan sudah bisa dianggap memiliki prospek yang baik dan jangka panjang. Berbeda dengan perusahaan yang relatif kecil, yang menghasilkan laba yang kecil pula. Berdasarkan berbagai penelitian yang telah dilakukan, maka penelitian ini bertujuan untuk menganalisis besarnya pengaruh return saham dengan menggunakan variabel independen yaitu laba akuntansi, arus kas operasi, arus kas investasi, arus kas pendanaan, dan ukuran perusahaan dengan objek penelitian yang merupakan perusahaan-perusahaan manufaktur sektor industri yang terdaftar pada Bursa Efek Indonesia (BEI) dalam periode waktu tahun 2014 sampai dengan tahun 2016.

\section{TINJAUAN PUSTAKA}

Teori agensi (agency theory). Teori agensi muncul karena adanya hubungan antara agent dengan principal. Hubungan keagenan merupakan suatu kontrak dimana satu atau lebih orang (prinsipal) memerintah orang lain (agen) untuk melakukan suatu jasa atas nama prinsipal serta memberikan wewenang kepada agen membuat keputusan yang terbaik bagi prinsipal. Jika kedua belah pihak tersebut mempunyai tujuan yang sama untuk memaksimumkan nilai perusahaan, maka diyakini agen akan mendukung dan melaksanakan semua yang diperintahkan oleh prinsipal. Teori agensi mendeskripsikan hubungan antara pemegang saham (shareholders) sebagai prinsipal dan manajemen sebagai agen. Manajemen merupakan pihak yang dikontrak oleh pemegang saham untuk bekerja demi kepentingan pemegang saham. Karena keduanya terpilih, maka pihak manejemen harus mempertanggungjawabkan semua pekerjaannya kepada pemegang saham. Selain itu, teori agensi ini juga menunjukkan pentingnya pemisahan fungsi antara manajemen perusahaan dan hubungan pemilik kepada manajer, dimana tujuan adanya pemisahan ini adalah untuk menciptakan efisiensi dan efektivitas dengan cara menyewa pihak profesional untuk mengelola perusahaan.

Teori pengelolaan (stewardship theory). Teori stewardship dibangun atas dasar asumsi filosofis mengenai sifat manusia, yaitu bahwa manusia pada hakikatnya dapat dipercaya, mampu bertindak dengan penuh tanggung jawab, memiliki integritas dan kejujuran terhadap pihak lain. Inilah yang tersirat dalam hubungan fidusia yaitu hubungan berlandaskan kepercayaan yang dikehendaki para stakeholder. Sehingga dalam teori stewardship ini, manajer dipandang sebagai seorang yang dapat dipercaya untuk melakukan tindakan yang sebaik-baiknya bagi kepentingan publik maupun stakeholders. Selain itu teori stewardship juga mengasumsikan hubungan yang kuat antara keberhasilan tujuan organisasi dengan kepuasan prinsipal. Stewardship ini akan melindungi dan memaksimalkan keuntungan yang dapat diperoleh organisasi dengan memaksimalkan kinerja perusahaan. 
Asumsi penting dari stewardship adalah manajer membentuk tujuannya agar sesuai dengan tujuan prinsipal, namun bukan berati stewardship ini tidak memiliki kebutuhan. Teori stewardship juga menjelaskan bentuk pola kepemimpinan dan hubungan para atasan dengan bawahannya dalam sebuah organisasi menggunakan mekanisme situasional. Mekanisme ini meliputi filosofis manajemen dan perbedaan budaya organisasi, serta kepemimpinan dalam pencapaian tujuan bersama tanpa mengorbankan kepentingan masing-masing (Anton, 2010).

Teori sinyal (signaling theory). Signaling theory merupakan sinyal informasi yang dibutuhkan oleh para investor untuk menentukan apakah investor tersebut akan menanamkan sahamnya pada perusahaan. Informasi yang dikeluarkan oleh perusahaan merupakan hal yang penting, karena pengaruhnya terhadap keputusan investasi terhadap pihak di luar perusahaan. Informasi tersebut penting bagi investor dan pelaku bisnis dimana informasi tersebut pada hakekatnya menyajikan keterangan, catatan atau gambaran, baik untuk keadaan masa lalu, saat ini maupun masa yang akan datang bagi kelangsungan hidup perusahaan dan bagaimana efeknya pada perusahaan. Banyak hal yang harus dipertimbangkan oleh investor untuk mengembangkan sahamnya yang dibuthkan oleh manajemen perusahaan dalam menentukan arah atau prospek perusahaan ke depan. Selanjutnya perusahaan dengan prospek yang menguntungkan akan mencoba menghindari penjualan saham dan mengusahakan modal baru dengan cara-cara lain seperti dengan menggunakan utang. Perusahaan dengan prospek yang kurang menguntungkan akan cenderung untuk menjual sahamnya. Teori sinyal menjelaskan mengapa manajer suatu entitas mempunyai insentif secara sukarela (voluntary) melaporkan informasi-informasi kepada pasar modal walaupun tidak ada ketentuan yang mengharuskan. Jama'an (2008) menyatakan bahwa signaling theory merupakan bagaimana seharusnya sebuah perusahaan memberikan sinyal kepada pengguna laporan keuangan. Sinyal ini berupa informasi mengenai apa yang sudah dilakukan oleh manajemen untuk merealisasikan keinginan pemilik. Sinyal dapat berupa promosi atau informasi lain yang menyatakan bahwa perusahaan tersebut lebih baik daripada perusahaan lain. Teori sinyal menjelaskan bahwa pemberian sinyal dilakukan oleh manajer untuk mengurangi asimetri informasi. Manajer memberikan informasi melalui laporan keuangan bahwa mereka menerapkan kebijakan akuntansi konservatisme yang menghasilkan laba yang lebih berkualitas karena prinsip ini mencegah perusahaan melakukan tindakan membesar-besarkan laba dan membantu pengguna laporan keuangan dengan menyajikan laba dan aktiva yang tidak overstate.

Laba akuntansi. Laba akuntansi merupakan laba bersih perusahaan yang dilaporkan dalam laporan laba rugi. Laporan laba rugi adalah laporan keuangan yang menggambarkan hasil-hasil usaha yang dicapai selama periode tertentu. Laba akuntansi didefinisikan sebagai perbedaan antara pendapatan yang di realisasikan dari transaksi yang terjadi selama satu periode dengan biaya yang berkaitan dengan pendapatan tersebut. Menurut Sa'adah dan Kadarusman (2014), terdapat dua hal yang dapat mempengaruhi laba akuntansi tahun berjalan yaitu discontinued operations dan extraordinary items. Laba akuntansi juga bisa berarti ukuran keseluruhan prestasi perusahaan yang diukur dengan menghitung selisih antara pendapatan dan biaya. Informasi laba sebenarnya dapat digunakan untuk memenuhi berbagai tujuan yaitu untuk menyediakan informasi yang bermanfaat bagi pihak yang berkepentingan. Menurut Pernyatan Standar Akuntansi No. 46 (PSAK 46) tentang Pajak Penghasilan, laba akuntansi adalah laba atau rugi selama suatu periode sebelum dikurangi beban pajak. Accounting profit is profit or loss for a period before deducting tax espenses (International Accounting Standard 12). Statement of Financial Accounting Concept (SFAC) No. 1 menyatakan bahwa informasi laba merupakan pehatian utama dalam menaksir kinerja atau pertanggungjawaban manajemen. Perusahaan yang mempunyai kemampuan untuk menghasilkan laba, cenderung harga sahamnya juga meningkat. Berarti apabila perusahaan mendapatkan laba yang semakin besar, maka secara teoritis perusahaan akan mampu membagikan dividen yang semakin besar. 
Arus kas operasi. Arus kas operasi dalam suatu perusahaan didapatkan dari hasil aktivitas pendapatan perusahaan (principal revenue activities) dan aktivitas lain yang bukan merupakan aktivitas investasi dan pendanaan. Selain itu, arus kas operasi juga berasal dari transaksi dan peristiwa lain yang mempengaruhi penetapan laba atau rugi bersih, serta merupakan indikator yang menentukan apakah dari operasi perusahaan dapat menghasilkan kas yang cukup untuk melunasi pinjaman, memelihara kemampuan operasi perusahaan, membayar dividen dan melakukan investasi baru tanpa mengandalkan sumber pendanaan dari luar. Kieso et al. (2014:205) memaparkan bahwa arus kas dari aktivitas operasi adalah "operating activities involve the cash effect of transactions that enter into the determination of net income, such as cash receipt from sales of goods and services and cash payments to supplier and employees for acquisition of inventory and expenses". Pernyataan ini mengartikan bahwa arus kas operasi mencakup pengaruh kas dari transaksi yang menghasilkan pedapatan dan beban, kemudian dimasukkan dalam penentuan laba bersih. Sumber kas ini umumnya dianggap sebagai ukuran terbaik dari kemampuan perusahaan dalam memperoleh dana yang cukup untuk dapat melanjutkan usahanya.

Arus kas investasi. Arus kas investasi dalam suatu perusahaan didapatkan dari aktivitas yang menyangkut perolehan atau pelepasan aktiva jangka panjang (aktiva tidak lancar) serta investasi lain yang tidak termasuk dalam setara kas, dimana dapat mencakup aktivitas meminjamkan uang dan mengumpulkan piutang serta memperoleh dan menjual investasi dan aktiva jangka panjang yang bersifat produktif, dimana arus kas investasi dapat mencerminkan pengeluaran kas sehubungan dengan sumber daya yang bertujuan untuk menghasilkan pendapatan dan arus kas masa depan. Kieso et al. (2014:205) menjelaskan bahwa arus kas investasi adalah "the investing activities generally involve non-current assets and include: (a) making collecting loans: and (b) acquiring and disposing of investment and productive long lived assets". Hal ini mengartikan bahwa arus kas investasi juga termasuk dalam proses melakukan penagihan pinjaman dan memperoleh dan melepaskan investasi (baik utang dan ekuitas) dan properti, pabrik, dan peralatan. Selain itu, dengan adanya peningkatan arus kas investasi pada perusahaan akan mampu memberikan arus kas tambahan bagi perusahaan meningkatkan pendapatannya. Peningkatan ini tentunya akan menarik investor maupun kreditor untuk melakukan transaksi di pasar modal.

Arus kas pendanaan. Arus kas dari aktivitas pendanaan adalah akibat dari transaksi atau peristiwa penerimaan kas dan pengeluaran kas kepada para pemegang saham yang disebut sebagai pendanaan ekuitas, sedangkan penerimaan kas dan pengeluaran kas kepada kreditor disebut sebagai pendanaan utang. Dengan kata lain, arus kas pendanaan dapat dikatakan sebagai suatu aktivitas yang mengakibatkan perubahan dalam jumlah serta komposisi modal dan pinjaman jangka panjang perusahaan. Pengungkapan arus kas yang timbul dari transaksi ini berguna untuk memprediksi klaim terhadap arus kas masa depan oleh para pemasok modal perusahaan. Berdasarkan pernyataan yang tertuang dalam PSAK No. 2 tahun 2017, arus kas pendanaan adalah aktivitas yang mengakibatkan perubahan dalam jumlah serta komposisi kontribusi modal dan pinjaman entitas. Arus kas yang timbul dari aktivitas pendanaan perlu dilakukan pengungkapan terpisah karena berguna untuk memprediksi klaim terhadap arus kas masa depan oleh para pemasok modal entitas. Menurut Kieso et al. (2014:205), arus kas dari aktivitas pendanaan adalah "financing activities involve liability and equity items and include: (a) obtaining cash from creditors and repaying the amounts borrowed; and (b) obtaining capital from owners, providing them with a return on, and a return of their investment", dimana arus kas pendanaan melibatkan item kewajiban dan ekuitas.

Ukuran perusahaan. Ukuran perusahaan merupakan gambaran besar kecilnya perusahaan yang ditunjukkan oleh nilai total aset perusahaan pada neraca akhir tahun, yang diukur dengan transformasi logaritma natural dari total aset. Perusahaan besar dianggap 
mempunyai kelebihan dibanding dengan perusahaan kecil. Perusahaan besar mempunyai sumber daya yang besar, sehingga relatif lebih tahan terhadap gejolak ekonomi dan tidak mudah bangkrut. Perusahaan besar mempunyai konsekuensi yang lebih besar apabila terjadi kebangkrutan, sehingga kemungkinan adanya campur tangan pemerintah untuk membantu juga besar. Hal ini diduga dapat memberikan kepercayaan yang lebih besar bagi para investor dalam langkah berinvestasi. Menurut Andriana et al. (2016), semakin besar aset maka semakin banyak modal yang ditanam, semakin banyak penjualan maka semakin banyak perputaran uang dan semakin besar pula perusahaan tersebut dikenal oleh masyarakat.

Return saham. Return merupakan tingkat keuntungan yang dinikmati oleh pemodal atas suatu investasi yang dilakukannya. Selain itu, return juga merupakan salah satu motivator investor untuk berinvestasi. Salah satu tujuan investor bermain saham memang untuk mencari return dari saham yang ditanamnya. Pasalnya, memang tidak ada investor yang ingin melakukan investasi jika memang tidak ada imbal balik berupa keuntungan yang didapatkan dari return saham itu sendiri. Return merupakan hasil yang diperoleh dari hasil investasi. Return dapat berupa return realisasi yang sudah terjadi atau return ekspektasi yang belum terjadi tetapi yang diharapkan akan terjadi di masa mendatang. Menurut Widowati (2013), return dapat berupa return realisasi (realized return) atau return ekspektasi (expected return). Salah satu faktor yang memotivasi para investor dalam berinvestasi adalah tingkat return yang akan diperoleh ketika menanamkan modalnya pada emiten tanpa mengabaikan risiko yang harus dihadapinya dimana semakin tinggi perubahan saham maka semakin tinggi return yang dihasilkan.

\section{METODE PENELITIAN}

Jenis dan sumber data. Penelitian ini merupakan penelitian asosiatif (hubungan), yang merupakan suatu penelitian yang bertujuan untuk mengetahui hubungan antara dua variabel atau lebih. Berdasarkan jenis data yang digunakan oleh peneliti, penelitian ini tergolong dalam penelitian kuantitatif karena mengacu pada perhitungan data berupa angka. Selain itu berdasarkan waktu pengumpulannya penelitian ini merupakan data panel, yaitu merupakan gabungan antara data cross section dan data time series, dimana unit cross section yang sama diukur pada waktu yang berbeda. Penelitian ini ditujukan untuk menjelaskan hubungan kausal antara variabel independen dan variabel dependen, yaitu variabel independen yang terdiri dari laba akuntansi, arus kas operasi, arus kas investasi, arus kas pendanaan, dan ukuran perusahaan terhadap variabel dependen yaitu return saham berdasarkan hipotesis yang dirumuskan.

Sampel dan teknik pengambilan sampel. Penelitian ini menggunakan perusahaan manufaktur sektor industri untuk konsumsi yang terdaftar di Bursa Efek Indonesia (BEI) periode 2014-2016. Penelitian ini menggunakan purposive sampling dimana sampel dipilih atas dasar kesesuaian karakteristik dan kriteria sampel yang ditentukan. Kriteria sampel dalam penelitian ini adalah sebagai berikut :

Tabel 1. Sampel penelitian

\begin{tabular}{lc}
\hline \multicolumn{1}{c}{ Kriteria data sampling } & Jumlah \\
\hline Perusahaan manufaktur sektor hasil industri untuk konsumsi yang terdaftar di BEI & 45 \\
& \\
Perusahaan manufaktur sektor industri terdaftar di BEI yang IPO (Initial Public Offering) & 6 \\
diantara tahun 2014-2016 & 39 \\
Jumlah sampel & 3 \\
Periode tahun penelitian & 117 \\
Jumlah data penelitian & \\
\hline
\end{tabular}


Berdasarkan kriteria tersebut terpilih 39 perusahaan sebagai sampel penelitian dengan menggunakan metode purposive sampling. Periode penelitian selama tiga tahun (2014-2016) sehingga jumlah data yang akan diteliti sebanyak 117 data. Tabel 2 menyajikan operasionalisasi variabel yang digunakan dalam penelitian ini.

Tabel 2. Definisi operasional variabel

\begin{tabular}{cll}
\hline Variabel & \multicolumn{1}{c}{ Rumus } & \multicolumn{1}{c}{ Keterangan } \\
\hline Laba Akuntansi & & $\Delta \mathrm{EAT}:$ Perubahan laba bersih \\
& $\Delta \mathrm{EAT}=\left(\mathrm{EAT}_{\mathrm{t}}-\mathrm{EAT}_{\mathrm{t}-1}\right)$ & $\mathrm{EAT}_{\mathrm{t}}:$ : Laba bersih periode $\mathrm{t}$ \\
& $/ \mathrm{TA}_{\mathrm{t}-1}$ & $\mathrm{EAT}_{\mathrm{t}-1}:$ Laba bersih periode $\mathrm{t}-1$ \\
& $\mathrm{TA}_{\mathrm{t}-1}:$ Total asset periode $\mathrm{t}-1$
\end{tabular}

Arus Kas Operasi

$$
\underset{\mathrm{TA}_{\mathrm{t}-1}}{\Delta \mathrm{AKO}=} \underset{\left(\mathrm{AKO}_{\mathrm{t}}-\mathrm{AKO}_{\mathrm{t}-1}\right) /}{(}
$$

Arus Kas Investasi

$$
\begin{aligned}
& \Delta \mathrm{AKI}=\left(\mathrm{AKI}_{\mathrm{t}}-\mathrm{AKI}_{\mathrm{t}-1}\right) / \\
& \mathrm{TA}_{\mathrm{t}-1}
\end{aligned}
$$

Arus Kas Pendanaan

$$
\begin{gathered}
\Delta \mathrm{AKP}= \\
\underset{\mathrm{TA}_{\mathrm{t}-1}}{\left(\mathrm{AKP}_{\mathrm{t}}-\mathrm{AKP}_{\mathrm{t}-1}\right) /}
\end{gathered}
$$

$$
\mathrm{SIZE}=\mathrm{Ln} \text { Total Assets }
$$

Return Saham

$$
\frac{R_{i t}=P_{i t}-P_{i t-1}}{P_{i t-1}}
$$

$\triangle \mathrm{AKO}:$ Perubahan arus kas operasi

$\mathrm{AKO}_{\mathrm{t}}$ : Arus kas operasi periode $\mathrm{t}$

$\mathrm{AKO}_{\mathrm{t}-1}$ :Arus kas operasi t-1

$\mathrm{TA}_{\mathrm{t}-1} \quad$ : Total asset periode $\mathrm{t}-1$

$\triangle \mathrm{AKI}:$ Perubahan arus kas investasi

$\mathrm{AKI}_{\mathrm{t}}$ : Arus kas investasi periode $\mathrm{t}$

$\mathrm{AKI}_{\mathrm{t}-1} \quad$ :Arus kas investasi t-1

$\mathrm{TA}_{\mathrm{t}-1} \quad$ : Total asset periode $\mathrm{t}-1$

$\triangle \mathrm{AKP}$ : Perubahan arus kas pendanaan

$\mathrm{AKP}_{\mathrm{t}}$ : Arus kas pendanaan periode $\mathrm{t}$

$\mathrm{AKP}_{\mathrm{t}-1}$ :Arus kas pendanaan t-1

$\mathrm{TA}_{\mathrm{t}-1} \quad$ : Total asset periode $\mathrm{t}-1$

$\mathrm{R}_{\mathrm{it}}$ : Return realisasi saham i period eke-t

$\mathrm{P}_{\text {it }}$ : Closing price saham i period ke-t

$\mathrm{P}_{\mathrm{it}-1}$ : Closing price saham i period ke-t

Metode analisis. Analisis untuk mengetahui seberapa besar suatu variabel independen mempengaruhi variabel dependen, hal ini dilakukan pada analisis regresi berganda pada tingkat signifikansi 5\%. Selain itu, penelitian ini melakukan analisis statistik deskriptif yang mengukur nilai minimum, nilai maksimum, nilai rata-rata, standar deviasi, dan range. Dalam rangka pengujian hipotesis, maka dilakukan tahap pengujian berikut.

1. Uji asumsi klasik, yang terdiri dari:

- Uji normalitas, yang bertujuan untuk menguji apakah residual error model regresi terdistribusi normal atau tidak. Salah satu model yang banyak digunakan untuk menguji normalitas adalah dengan uji Jarque-Bera. Uji Jarque-Bera mempunyai nilai Chi-Square dengan derajat bebas dua dan dapat dilihat dengan kriteria berikut: (a) jika hasil uji Jarque-Bera lebih besar dari nilai Chi-Square pada $\alpha=5 \%$, maka hipotesis nol diterima yang berarti residual error dari modelregresi berdistribusi normal; dan (b) jika hasil uji Jarque-Bera lebih kecil dari nilai Chi-Square pada $\alpha=5 \%$, maka hipotesis nol ditolak yang artinya residual error dari model regresi tidak berdistribusi normal. 
- Uji multikolinearitas, yang bertujuan untuk menguji apakah pada model regresi ditemukan adanya korelasi antar variabel independen. Jika hasil penelitian menunjukkan nilai Variance Inflation Factor (VIF) $\geq 10$ berarti menunjukkan adanya unsur multikolinearitas, sebaliknya jika nilai VIF $<10$ berarti tidak mengandung unsur multikolinearitas atau bebas multikolinearitas.

- Uji heteroskedastisitas, yang bertujuan menguji suatu pelanggaran asumsi dalam persamaan regresi berganda dimana residual error memiliki varians yang tidak.

2. Analisis korelasi yaitu merupakan teknik analisis yang termasuk dalam salah satu teknik pengukuran asosiasi/hubungan. Pengukuran asosiasi merupakan istilah umum yang mengacu pada sekelompok teknik dalam statistik bivariate yang digunakan pada sekelompok teknik dalam statistik bivariate yang digunakan untuk mengukur kekuatan hubungan antara dua variabel.

3. Koefisien determinasi yaitu pengujian untuk menguji sejauh mana variasi dari variabel terkait yang mampu dijelaskan pada variabel bebasnya, dimana nilai $\mathrm{R}^{2}$ berkisar antara 0 1 persen jika nilai mendekati angka 1 maka semakin baik.

4. Analisis regresi berganda yang merupakan estimasi parameter model dengan data panel dengan menggunakan beberapa teknik penentuan data, yaitu: (a) Model Common Effect (Ordinary Least Square) yang merupakan model paling sederhana dimana dalam estimasinya diasumsikan bahwa setiap unit individu memiliki intercept dan slope yang sama (tidak ada perbedaan pada dimensi ketat waktu) atau dengan kata lain, regresi data panel data yang dihasilkan akan berlaku untuk setiap individu; (b) The Fixed Effect Model (FEM) atau model efek tetap yaitu merupakan model regresi data panel yang didapatkan dengan asumsi bahwa unit cross section dan time series yang digunakan dalam model sudah diketahui terlebih dahulu, FEM dalam penelitian ini memiliki konstanta yang bervariasi pada unit cross section dan koefisien konstanta yang mengasumsikan bahwa perbedaan pengaruh dari unit cross section dan time series tercermin dari konstanta yang berbeda-beda; dan (c) The Random Effect Model atau Model Efek Random dimana model ini disebut juga model komponen error. Sama seperti model efek tetap, model ini juga memungkinkan terjadi perbedaan nilai parameter intersep dan koefisien berbeda antar daerah dan antar waktu, yang diekspresikan dalam error. Pada model ini gangguan diasumsikan bersifat acak untuk seluruh populasi. Model ini mengasumsikan bahwa error secara individu tidak saling berkorelasi, begitu juga dengan error kombinasinya. Dengan menggunakan model ini maka kita dapat menghemat pemakaian derajat kebebasan dan tidak mengurangi jumlah seperti pada fixed effect model dimana hal ini berimplikasi pada parameter hasil estimasi akan menjadi efisien.

\section{HASIL PENELITIAN DAN PEMBAHASAN}

\subsection{Hasil penelitian}

Objek data yang dianalisa dalam penelitian ini adalah laporan keuangan perusahaan manufaktur sub sektor barang konsumsi periode 2014-2016. Return merupakan variabel dependen dan laba akuntansi, arus kas operasi, arus kas investasi, arus kas pendanaan dan ukuran perusahaan merupakan variabel independen yang keseluruhan variabel diukur menggunakan rasio. Untuk dapat melihat deskripsi hasil tabulasi sampel dari semua penelitian, diperlukan analisis statistik deskriptif yang berdasar pada nilai minimum, nilai maksimum, mean dan standar deviasi. Tabel 3 menunjukkan bahwa return saham memiliki nilai rata-rata (mean) sebesar 7.155895, standar deviasi sebesar 1.726112, nilai maksimum sebesar 11.06506, dan nilai minimum sebesar 4.127134 yang artinya nilai datanya bervariasi. Laba akuntansi memiliki nilai rata-rata (mean) sebesar 948,364.4, nilai maksimum sebesar 12,762,229, dan nilai minimum sebesar -2,278,718 yang artinya nilai datanya bervariasi. Arus kas operasi memiliki nilai rata-rata (mean) sebesar 937,813.8, nilai maksimum sebesar 
14,076,579, dan nilai minimum sebesar -2823747 yang artinya nilai datanya bervariasi. Arus kas investasi memiliki nilai rata-rata (mean) -655,648.1, nilai maksimum sebesar 259,101.8, dan nilai minimum sebesar $-17,479,008$ yang artinya nilai datanya bervariasi. Arus kas pendanaan memiliki nilai rata-rata (mean) sebesar -577,320.9, nilai maksimum sebesar $4,439,653$, dan nilai minimum sebesar $-12,250,485$ yang artinya nilai datanya bervariasi. Ukuran perusahaan memiliki nilai rata-rata (mean) sebesar 14.59788, nilai maksimum sebesar 18.33547, dan nilai minimum sebesar 11.80434 yang artinya nilai datanya bervariasi.

Tabel 3. Statistik deskriptif

\begin{tabular}{lcccccc}
\hline & LOG RETURN & LABA & AKO & AKI & AKP & SIZE \\
\hline Mean & 7.155895 & 948364.4 & 937813.8 & -655648.1 & -577320.9 & 14.59788 \\
Median & 7.105786 & 134727.2 & 160700.0 & -77401.13 & -10305.41 & 14.24167 \\
Maximum & 11.06506 & 12762229 & 14076579 & 259101.8 & 4439653. & 18.33547 \\
Minimum & 4.127134 & -2278718. & -2823747. & -17479008 & -12250485 & 11.80434 \\
Std. Dev. & 1.726112 & 2320798. & 2397883. & 2028277. & 2315081. & 1.544517 \\
Skewness & 0.390212 & 2.895049 & 3.075514 & -6.115186 & -3.217100 & 0.605382 \\
Kurtosis & 2.285499 & 12.00451 & 13.69408 & 46.01168 & 14.79029 & 2.724206 \\
Jarque-Bera & 5.457918 & 558.7062 & 741.9676 & 9747.984 & 879.4978 & 7.517310 \\
Probability & 0.065287 & 0.000000 & 0.000000 & 0.000000 & 0.000000 & 0.023315 \\
Sum & 837.2397 & $1.11 \mathrm{E}+08$ & $1.10 \mathrm{E}+08$ & -76710823 & -67546544 & 1707.952 \\
Sum Sq. Dev. & 345.6178 & $6.25 \mathrm{E}+14$ & $6.67 \mathrm{E}+14$ & $4.77 \mathrm{E}+14$ & $6.22 \mathrm{E}+14$ & 276.7218 \\
Observations & 117 & 117 & 117 & 117 & 117 & 117 \\
\hline
\end{tabular}

LABA adalah laba akuntansi, AKO adalah arus kas operasi. AKI adalah arus kas investasi, AKP adalah arus kas pendanaan, dan SIZE adalah ukuran perusahaan.

Gambar 1 menunjukkan bahwa nilai Jarque-Bera sebesar 3,054062 dengan nilai probabilitas sebesar 0,217179 dimana nilai probabilitas lebih besar dari 0,05 yang berarti bahwa nilai residual error berdistribusi normal.

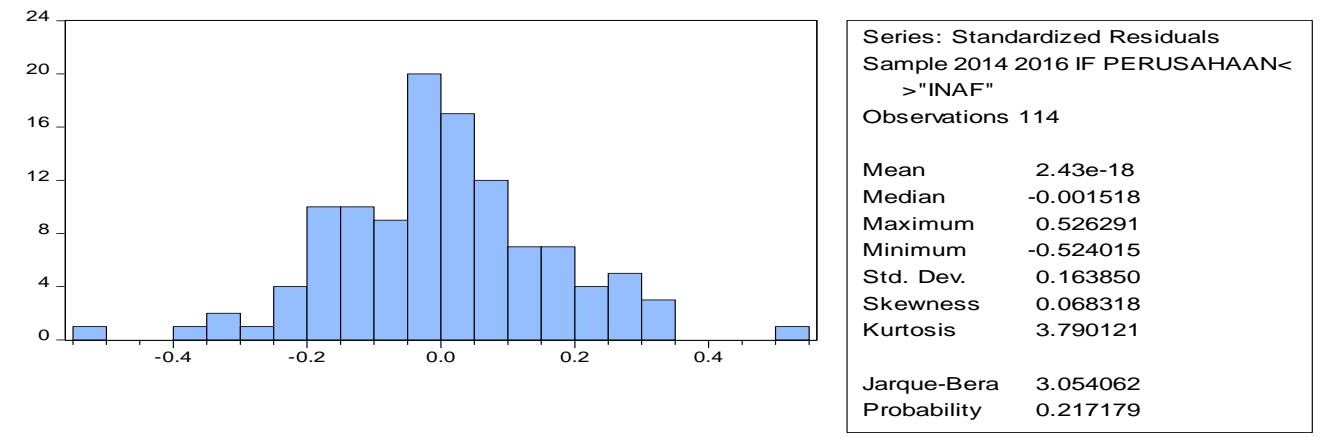

Gambar 1. Uji normalitas

Tabel 4 menunjukkan bahwa Centered Inflation Factors (VIF) antar variabel independen dan dependen memiliki nilai kurang dari 10 sehingga dapat disimpulkan bahwa tidak terjadi multikolinearitas antar variabel independen dalam model penelitian ini.

Tabel 4. Uji multikolinieritas

\begin{tabular}{lcccccc}
\hline & LOG RETURN & LABA & AKO & AKI & AKP & SIZE \\
\hline LOG RETURN & 1.000000 & 0.475184 & 0.430257 & -0.291434 & -0.300134 & 0.501373 \\
LABA & 0.475184 & 1.000000 & 0.882012 & -0.401118 & -0.850976 & 0.660243 \\
AKO & 0.430257 & 0.882012 & 1.000000 & -0.409268 & -0.809846 & 0.622215 \\
AKI & -0.291434 & -0.401118 & -0.409268 & 1.000000 & 0.295566 & -0.519635 \\
AKP & -0.300134 & -0.850976 & -0.809846 & 0.295566 & 1.000000 & -0.449308 \\
SIZE & 0.501373 & 0.660243 & 0.622215 & -0.519635 & -0.449308 & 1.000000 \\
\hline
\end{tabular}

LABA adalah laba akuntansi, AKO adalah arus kas operasi. AKI adalah arus kas investasi, AKP adalah arus kas pendanaan, dan SIZE adalah ukuran perusahaan. 
Tabel 5 menunjukkan bahwa hasil uji heteroskedastisitas memiliki nilai variance tetap maka dapat dikatakan tidak terjadi masalah heteroskedastisitas.

Tabel 5. Uji heteroskedastisitas

\begin{tabular}{lcccc}
\hline \multicolumn{1}{c}{ Variable } & Coefficient & Std. Error & t-Statistic & Prob. \\
\hline C & 580.4835 & 2009.086 & 0.288929 & 0.7735 \\
LABA & $2.67 \mathrm{E}-05$ & 0.000208 & 0.128555 & 0.8981 \\
AKO & $-5.31 \mathrm{E}-06$ & $4.97 \mathrm{E}-05$ & -0.106829 & 0.9152 \\
AKI & $2.64 \mathrm{E}-05$ & $3.20 \mathrm{E}-05$ & 0.824881 & 0.4121 \\
AKP & $-4.38 \mathrm{E}-05$ & $5.03 \mathrm{E}-05$ & -0.871810 & 0.3862 \\
SIZE & -10.54484 & 139.3125 & -0.075692 & 0.9399 \\
\hline R-squared & 0.823981 & Mean dependent var & 454.8525 & \\
Adjusted R-squared & 0.720298 & S.D. dependent var & 846.3011 & \\
S.E. of regression & 447.5819 & Akaike info criterion & 15.32602 & \\
Sum squared resid & 14624061 & Schwarz criterion & 16.36478 & \\
Log likelihood & -852.5721 & Hannan-Quinn criter. & 15.74774 & \\
F-statistic & 7.947148 & Durbin-Watson stat & 3.692294 & \\
Prob (F-statistic) & 0.000000 & & & \\
Dependent variable: ABS (RESIDUAL) & & & &
\end{tabular}

Tabel 6 menunjukkan bahwa semua variabel independen berkorelasi dengan variabel dependen. Hal ini berarti bahwa antara variabel independen memiliki hubungan dengan variabel dependen.

Tabel 6. Hasil analisis korelasi

\begin{tabular}{lcccc}
\hline \multicolumn{1}{c}{ Variable } & Coefficient & Std. Error & t-Statistic & Prob. \\
\hline C & 5.336533 & 1.519157 & 3.513 & 0.0008 \\
LABA & $2.48 E-07$ & $9.03 E-08$ & 2.745 & 0.0077 \\
AKO & $-3.60 E-08$ & $9.57 E-09$ & -3.759 & 0.0003 \\
AKI & $-2.52 E-09$ & $5.29 E-09$ & -0.476 & 0.6354 \\
AKP & $-6.66 E-09$ & $1.22 E-08$ & -0.547 & 0.586 \\
SIZE & 0.111212 & 0.104737 & 1.062 & 0.2919 \\
\hline R-squared & 0.991027 & Mean dependent var & 7.173698 & \\
Adjusted R-squared & 0.985719 & S.D. dependent var & 1.729741 & \\
S.E. of regression & 0.206707 & Akaike info criterion & -0.034157 \\
Sum squared resid & 3.033686 & Schwarz criterion & 0.997918 \\
Log likelihood & 44.94695 & Hannan-Quinn criter. & 0.384704 & \\
F-statistic & 186.7087 & Durbin-Watson stat & 2.947869 \\
Prob (F-statistic) & 0 & & &
\end{tabular}

Pengujian hipotesis dilakukan dengan melakukan analisis regresi berganda melalui beberapa model pengujian yaitu Common Efect Model, Fixed Effect Model dan Random Effect Model. Tahap pertama yang dilakukan yaitu uji Chow, dimana Tabel 7 menunjukkan bahwa hasil uji Chow memiliki nilai probabilitas pada F-test sebesar 0,0000 dan nilai ChiSquare sebesar 0,0000, kedua nilai tersebut lebih kecil dari 0,05 sehingga dapat disimpulkan bahwa model mengikuti Fixed Effect Model (FEM).

Tabel 7. Uji Chow

\begin{tabular}{lccc}
\hline \multicolumn{1}{c}{ Effects Test } & Statistic & d.f. & Prob. \\
\hline Cross-section F & 166.619567 & $(38,73)$ & 0.0000 \\
Cross-section Chi-square & 523.493510 & 38 & 0.0000 \\
\hline
\end{tabular}

Tahap kedua yang dilakukan yaitu Uji Hausman, dimana pada Tabel 8 menunjukkan bahwa hasil uji Hausman memiliki nilai Chi-Square sebesar 0,0000 dan lebih kecil dari 0,05 
sehingga dapat disimpulkan bahwa menurut uji Hausman, model mengikuti Fixed Effect Model (FEM).

Tabel 8. Uji Hausman

\begin{tabular}{cccc}
\hline Test Summary & Chi-Sq. Statistic & Chi-Sq. d.f. & Prob. \\
\hline Cross-section random & 54.549932 & 5 & 0.0000 \\
\hline
\end{tabular}

Berdasarkan Tabel 9, hasil analisis regresi berganda menunjukkan bahwa nilai probabilitas laba akuntansi (LABA) memiliki nilai prob 0,0077 < 0,05 maka H1 diterima, dan H0 ditolak sehingga laba akuntansi secara parsial berpengaruh signifikan terhadap return saham. Arus Kas Operasi (AKO) memiliki nilai prob 0,0003 < 0,05 maka H1 diterima, dan H0 ditolak sehingga arus kas dari aktivitas operasi secara parsial berpengaruh signifikan terhadap return saham. Arus Kas Investasi (AKI) memiliki nilai prob 0,6354 > 0,05 maka H1 ditolak, dan $\mathrm{H} 0$ diterima sehingga arus kas dari aktivitas investasi secara parsial tidak signifikan terhadap return saham. Arus Kas Pendanaan (AKP) memiliki nilai prob 0,5860 > 0,05 maka H1 ditolak, dan H0 diterima sehingga arus kas dari aktivitas pendanaan secara parsial tidak signifikan terhadap return saham. Ukuran perusahaan (SIZE) memiliki nilai prob 0,2919 > 0,05 maka H1 ditolak, dan H0 diterima sehingga ukuran perusahaan secara parsial tidak signifikan terhadap return saham. Tabel 9 juga menunjukkan bahwa nilai RSquared sebesar 0,997173 sehingga besarnya nilai koefisien determinasi adalah sebesar sebesar 0.985719, hal ini berarti variabel laba akuntansi, arus kas operasi, arus kas investasi, arus kas pendanaan, dan ukuran perusahaan mampu menjelaskan variabel return saham sebesar 98,5\% dan 11,5\% nilai varibael return saham yang dijelaskan oleh faktor lain diluar variabel bebas yang tidak terkandung dalam penelitian. Persamaan regresi yang dihasilkan dari Tabel 9 adalah sebagai berikut:

RETURN=5.336+2.479LABA-3.596AKO-2.517AKI-6.662AKP $+0.1112 \mathrm{SIZE}+\varepsilon$

Tabel 9. Analisis regresi berganda Model Fixed Effect Model

\begin{tabular}{|c|c|c|}
\hline Variable & Coefficient & Prob. \\
\hline $\mathrm{C}$ & 5.336533 & 0.0008 \\
\hline LABA & $2.48 \mathrm{E}-07$ & 0.0077 \\
\hline $\mathrm{AKO}$ & $-3.60 \mathrm{E}-08$ & 0.0003 \\
\hline AKI & $-2.52 E-09$ & 0.6354 \\
\hline AKP & $-6.66 \mathrm{E}-09$ & 0.586 \\
\hline SIZE & 0.111212 & 0.2919 \\
\hline $\mathrm{R}^{2}$ & 0.985719 & \\
\hline
\end{tabular}

LABA adalah laba akuntansi, AKO adalah arus kas operasi. AKI adalah arus kas investasi, AKP adalah arus kas pendanaan, dan SIZE adalah ukuran perusahaan

\subsection{Pembahasan}

Laba akuntansi dan return saham

Hasil uji hipotesis menunjukkan bahwa koefisien regresi positif 2,48 dengan tingkat signifikansi yang diperoleh atas profitabilitas menunjukkan signifikansi sebesar 0,0077 lebih kecil dari tingkat signifikansi $0,05(0,0077<0,05)$ dapat dinyatakan bahwa laba akuntansi $\left(\mathrm{X}_{1}\right)$ berpengaruh terhadap return saham. Hasil penelitian ini sejalan dengan Yocelyn dan Chistiawan (2012), Purwanti et al. (2015), Putra dan Widyaningsih (2016) yang memaparkan bahwa bahwa pelaku pasar/investor masih mempertimbangkan informasi yang terkandung dalam laba akuntansi yang diperoleh perusahaan sebagai dasar tolak ukur investor dalam membuat keputusan investasinya. Sama halnya dengan pernyataan yang tertuang dalam Statement of Financial Accounting Concept (SFAC) No. 1 menyatakan bahwa informasi laba merupakan perhatian utama dalam menaksir kinerja atau pertanggung jawaban manajemen. 


\section{Arus kas operasi dan return saham}

Hasil uji hipotesis yang dilakukan, variabel arus kas operasi menunjukkan bahwa koefisien regresi negatif 3,60 dengan tingkat signifikansi sebesar 0,0003 lebih kecil dari tingkat signifikansi $0,05(0,0003<0,05)$ dapat dinyatakan bahwa arus kas operasi $\left(\mathrm{X}_{2}\right)$ berpengaruh secara signifikan terhadap return saham. Hasil penelitian ini sejalan dengan Putra dan Widyaningsih (2016). Arus kas operasi merupakan faktor yang dapat berpengaruh terhadap pengungkapan return saham dalam suatu perusahaan, dimana dapat dinyatakan bahwa investor mempunyai anggapan bahwa arus kas dari aktivitas operasi memiliki kandungan informasi yang merupakan cerminan kemampuan perusahaan dalam menghasilkan kas dan setara kas yang cukup untuk melunasi pinjaman, memelihara kemampuan operasi perusahaan, membayar dividen, dan melakukan investasi baru tanpa mengandalkan sumber pendanaan dari luar sesuai dengan pernyataan yang tertuang dalam PSAK No.2 paragraf 12 (revisi tahun 2017), bahwa arus kas aktivitas operasi digunakan investor sebagai dasar tolak ukur keputusan investasi.

\section{Arus kas investasi dan return saham}

Hasil uji hipotesis yang dilakukan pada variabel arus kas investasi menunjukkan bahwa koefisien regresi negatif 2,52 dengan tingkat signifikansi 0,6354 diatas tingkat signifikansi $0,05(0,6354>0,05)$ menunjukkan bahwa hipotesis ke tiga tidak didukung atau $\mathrm{H} 0$ diterima. Penelitian ini berhasil membuktikan bahwa arus kas investasi $\left(\mathrm{X}_{3}\right)$ tidak signifikan terhadap return saham. Hasil penelitian ini sejalan dengan Yocelyn dan Chistiawan (2012), dan Purwanti et al. (2015) yang menemukan bahwa investor mempunyai anggapan arus kas dari aktivitas investasi tidak memiliki kandungan informasi yang dapat dijadikan investor sebagai dasar pengambilan keputusan investasi. Penelitian tersebut membuktikan bahwa arus kas investasi tidak berpengaruh terhadap return saham dan bertentangan dengan penelitian Rhamedia (2015) serta Mas'ut dan Sijabat (2017) yang menyatakan bahwa laba akuntansi tidak memiliki pengaruh terhadap return saham.

\section{Arus kas pendanaan dan return saham}

Hasil uji hipotesis yang dilakukan pada variabel arus kas pendanaan menunjukkan bahwa koefisien regresi negatif 6,66 dengan tingkat signifikansi 0,5860 diatas tingkat signifikansi $0,05(0,5860>0,05)$ menunjukkan bahwa hipotesis ke tiga tidak didukung atau $\mathrm{HO}$ diterima. Penelitian ini berhasil membuktikan bahwa arus kas pendanaan $\left(\mathrm{X}_{4}\right)$ tidak signifikan terhadap return saham. Hasil penelitian ini sejalan dengan Sinaga dan Pamudji (2010), Yocelyn dan Chistiawan (2012), dan Purwanti et al. (2015) dimana investor mempunyai anggapan arus kas dari aktivitas pendanaan tidak memiliki kandungan informasi yang dapat dijadikan investor sebagai dasar pengambilan keputusan investasi.

\section{Ukuran perusahaan dan return saham}

Hasil uji hipotesis yang dilakukan pada variabel ukuran perusahaan menunjukkan bahwa koefisien regresi positif 0,11 dengan tingkat signifikansi 0,2919 diatas tingkat signifikansi $0,05(0,2919>0,05)$ yang menunjukkan bahwa hipotesis ke tiga tidak didukung atau H0 diterima. Penelitian ini berhasil membuktikan bahwa ukuran perusahaan $\left(\mathrm{X}_{5}\right)$ tidak signifikan terhadap return saham. Hasil penelitian ini mendukung Setiyono dan Amanah (2016), dan Nadiyah dan Suryono (2017) tapi tidak sejalan dengan Munte (2010). Berdasarkan hasil penelitian tersebut dapat dinyatakan bahwa pertumbuhan suatu perusahaan bukan hanya dilihat dari besar kecilnya ukuran perusahaan akan tetapi melihat pada besarnya suatu aset yang dimiliki oleh perusahaan dimana bila tidak dapat dikelola dengan baik oleh suatu perusahaan untuk kegiatan operasi suatu perusahaan, maka tidak akan dapat 
menghasillkan laba yang besar, laba yang tidak maksimal akan membuat harga saham menurun.

Laba akuntansi, arus kas operasi, arus kas investasi, arus kas pendanaan, ukuran perusahaan, dan return saham

Hasil pengujian ini dibuktikan bahwa seluruh variabel yang diujikan didapat bahwa $\mathrm{Ha}_{6}$ dapat diterima dimana pelaksanaan atas laba akuntansi, arus kas operasi, arus kas investasi, dan arus kas pendanaan serta ukuran perusahaan berpengaruh terhadap return saham dimana hasil regresi data panel menunjukkan nilai $\mathrm{f}_{\text {hitung }}$ sebesar 186,7 dan secara bersama-sama variabel independen memiliki nilai prob (F-stat) 0,000 dimana nilai tersebut lebih kecil dari $0,05(0,000<0,05)$ sehingga variabel independen secara bersama-sama memiliki pengaruh secara simultan terhadap variabel dependennya.

\section{KESIMPULAN DAN SARAN}

\subsection{Kesimpulan}

Berdasarkan hasil analisis dan pembahasan, maka kesimpulan yang didapat diantaranya adalah sebagai berikut: (1) laba akuntansi berpengaruh signifikan terhadap return saham pada perusahaan manufaktur sektor industri untuk konsumsi yang terdaftar di Bursa Efek Indonesia periode 2014-2016; (2) arus kas dari aktivitas operasi berpengaruh signifikan terhadap return saham pada perusahaan manufaktu sektor industri untuk konsumsi yang terdaftar di Bursa Efek Indonesia periode 2014-2016; (3) arus kas dari aktivitas investasi tidak signifikan terhadap return saham pada perusahaan manufaktur sektor industri untuk konsumsi yang terdaftar di Bursa Efek Indonesia periode 2014-2016; (4) arus kas dari aktivitas pendanaan tidak signifikan terhadap return saham pada perusahaan manufaktur sektor industri untuk konsumsi yang terdaftar di Bursa Efek Indonesia periode 2014-2016; (5) ukuran perusahaan tidak signifikan terhadap return saham pada perusahaan manufaktur sektor industri untuk konsumsi yang terdaftar di Bursa Efek Indonesia periode 2014-2016; dan (6) laba akuntansi, arus kas operasi, arus kas investasi, arus kas pendanaan dan ukuran perusahaan secara bersama-sama berpengaruh terhadap return saham pada perusahaan manufakturing sektor industri untuk konsumsi yang terdaftar di Bursa Efek Indonesia periode 2014-2016.

\subsection{Saran}

Penelitian ini masih memiliki keterbatasan antara lain dalam penelitian ini peneliti hanya dapat menunjukkan 98,5\% variabel dependen yaitu return saham yang dapat dijelaskan oleh variabel independen yakni meliputi bahwa laba akuntansi, arus kas operasi, arus kas investasi, arus kas pendanaan dan ukuran perusahaan sedangkan sisanya sebesar 11,5\% dipengaruhi oleh faktor lain. Untuk itu penelitian selanjutnya diharapkan dapat menambah variabel independen lainnya diluar variabel independen penelitian ini yang bertujuan untuk melihat pengaruh variabel lain terhadap variabel dependen khususnya mengenai return saham pada perusahaan sektor industri untuk konsumsi.

\section{DAFTAR PUSTAKA}

Andriana, S., Halim, A., \& Sari, A. R. (2016). Analisis pengaruh laba akuntansi, total arus kas dan size perusahaan terhadap return saham pada perusahaan manufaktur yang terdaftar di Bursa Efek Indonesia. Journal Riset Mahasiswa Akuntansi, 4(1), 1-12. http://ejournal.unikama.ac.id/index.php/jrma/article/view/1300 
Anwar, A. (2014). Pengaruh arus kas dari aktivitas operasi dan laba akuntansi terhadap return saham perusahaan industri manufaktur yang terdaftar di BEI. Jurnal Akuntansi, 2(3), 1-19. http://ejournal.unp.ac.id/students/index.php/akt/article/view/1573

Anton, F. X. (2010). Menuju teori stewardship managemen. Majalah Ilmiah Informatika, 1(2), 61-80. $\quad$ https://www.unaki.ac.id/ejournal/index.php/majalah-ilmiahinformatika/article/view/10

Daniati, N., \& Suhairi. (2006). Pengaruh kandungan informasi komponen laporan arus kas, laba kotor dan size perusahaan terhadap expected return saham. Simposium Nasional Akuntansi 9 Padang, 1-23. http://blog.umy.ac.id/ervin/files/2012/06/K-AKPM-21.pdf

Ikatan Akuntan Indonesia, (2017). Pernyataan Standar Akuntansi Keuangan (PSAK No 2) revisi 2017 laporan arus kas. Jakarta: Salemba Empat.

Ikatan Akuntan Indonesia, (2017). Pernyataan Standar Akuntansi Keuangan (PSAK No 46), revisi 2017 laporan arus kas. Jakarta: Salemba Empat.

Jama'an. (2008). Pengaruh mekanisme Corporate Governance dan kualitas kantor akuntan publik terhadap integritas informasi laporan keuangan (Studi kasus perusahaan publik yang listing di BEJ). Tesis. Universitas Diponegoro. http://eprints.undip.ac.id/17940/

Kieso, D. E., Weygandt, J. J., \& Warfield, T. D. (2014). Intermediate accounting IFRS Edition 2nd ed. United States of America: Wiley.

Latief, W. F., \& Purwanto, A. (2015). Pengaruh komponen arus kas, laba akuntansi dan dividend yield terhadap return saham (Studi empiris pada perusahaan manufaktur di BEI periode 2011-2013). Diponegoro Jurnal of Accounting, 4(2), 1-11. https://ejournal3.undip.ac.id/index.php/accounting/article/view/15974

Mas'ut., \& Sijabat, N. (2017). Pengaruh informasi laba, total arus kas dan komponen arus kas terhadap harga saham pada perusahaan dagang yang terdaftar di Bursa Efek Indonesia. Jurnal Riset Akuntansi Multiparadigma (JRAM), 4(3), 42-48. https://jurnal.uisu.ac.id/index.php/JRAM/article/view/331

Munte, M. H. M. (2010). Pengaruh faktor fundamental terhadap return saham pada perusahaan manufaktur yang terdaftar di Bursa Efek Indonesia. Tesis. Universitas Sumatera Utara. Medan. http://repository.usu.ac.id/handle/123456789/4030

Nadiyah, F., \& Suryono, B. (2017). Pengaruh kinerja keuangan dan ukuran perusahaan terhadap return saham. Jurnal Ilmu dan Riset Akuntansi, 6(9), 1-15. http://jurnalmahasiswa.stiesia.ac.id/index.php/jira/article/view/1586

Putra, Y. R., \& Widyaningsih, M. (2016). Pengaruh laba akuntansi, komponen arus kas, dan dividend yield terhadap return saham (Studi pada perusahaan sektor pertambangan di Bursa Efek Indonesia periode 2012-2014). Jurnal Riset Akuntansi dan Keuangan, 4(2), 108-120. https://ejournal.upi.edu/index.php/JRAK/article/view/4039

Purwanti, S., Chomsatu, Y., \& Masitoh W. E. (2015). Pengaruh laba akuntansi dan arus kas terhadap return saham yang listing di BEI. Jurnal Akuntansi dan Pajak, 16(1), 113123. http://www.jurnal.stie-aas.ac.id/index.php/jap/article/view/27

Rhamedia, H. (2015). Pengaruh informasi arus kas, laba akuntansi, dan ukuran perusahaan terhadap harga saham (Studi empiris pada perusahaan LQ45 yang terdaftar di PT. BEI. Jurnal Akuntansi, $1-27$. http://ejournal.unp.ac.id/students/index.php/akt/article/view/1614

Sa'adah, L., \& Kadarusman. (2014). Pengaruh laba akuntansi, komponen arus kas, ukuran perusahaan terhadap harga saham pada perusahaan kelompok LQ-45 yang listing di Bursa Efek Indonesia. Jurnal Manajemen dan Akuntansi, 3(2), 15-30. http://publishing-widyagama.ac.id/ejournal-v2/index.php/jma/article/view/254

Setiyono, E., \& Amanah, L. (2016). Pengaruh kinerja keuangan dan ukuran perusahaan terhadap return saham. Jurnal Ilmu dan Riset Akuntansi, 5(5), 1-17. http://jurnalmahasiswa.stiesia.ac.id/index.php/jira/article/view/329 
Sinaga, H. H., \& Pamudji, S. (2010). Analisis pengaruh total arus kas, komponen arus kas, laba akuntansi terhadap return saham. Skripsi. Universitas Diponegoro. http://eprints.undip.ac.id/26499/

Widowati, E. (2013). Pengaruh laba akuntansi dan arus kas terhadap return saham syariah yang terdaftar di Jakarta Islamic Index tahun 2007-2008. Jurnal Ilmiah Wahana Akuntansi, $\quad$ 8(2), 137-148. http://journal.unj.ac.id/unj/index.php/wahanaakuntansi/article/view/859

Yocelyn, A., \& Chistiawan, Y. J. (2012). Analisis pengaruh perubahan arus kas dan laba akuntansi terhadap return saham pada perusahaan berkapitalisasi besar. Jurnal Akuntansi dan Keuangan, 14(2), 81-90. https://doi.org/10.9744/jak.14.2.81-90 